\title{
Naseem Hijazi - An Uncelebrated Hero of the Pakistan Movement
}

\author{
Ghulam Shabir ${ }^{1}$, Qamar-ud-Din Zia Ghaznavi ${ }^{2}$, Ghulam Safdar ${ }^{1}$, Abdul Wajid Khan ${ }^{1}$, \\ Muhammad Umair Chaudhary, ${ }^{1, *}$ \\ ${ }^{1}$ Department of Media Studies, The Islamia University of Bahawalpur, Pakistan \\ ${ }^{2}$ University of Central Punjab, Lahore
}

Copyright (C) 2015 Horizon Research Publishing All rights reserved.

\begin{abstract}
This paper elaborates the life of Mr. Naseem Hijazi an uncelebrated hero of the Pakistan Movement. The major purpose of this paper is to high light the hidden aspects about the life of Mr. Naseem Hijazi. He was not only a great writer, Novelist but he was also a freedom fighter. He contributed in Pakistan Movement, about this aspect of his life very few peoples know. He was not only a true Muslim but also a great follower of Islam. In this research paper, life of Naseem Hijazi is studied and analyzed to get a true picture about him.
\end{abstract}

Keywords Pakistan Movement, Historic Writer, Novelist, Freedom Fighter

\section{Introduction}

Sharif Husain, who used the pen name Naseem Hijazi, was born in 19th May 1914 was a Urdu writer. He was born at the village of Sujaanpur near town Dhariwal, district Gurdaspur, Punjab in Pre-Partition India and migrated to Pakistan after independence from the British Rule and the subsequent partition of India in 1947. He lived most of his life in Pakistan and died in March 1996.

Naseem Hijazi's ancestors belonged to Hijaz and they lived in Gurdaspur, East Punjab. Naseem Hijazi was born in a village named SojaanPur. He was born in the family of Chaudhary Jaan Muhammad. His father was a government servant in Canal department. He was deprived of his mother in his childhood period very soon. He got primary education in his native village but he did his BA from Islamia College Lahore in1938. In the meanwhile he had hold pen in his hand and had started writing. First of all he pen crafted "Shader" as a fiction. By: that time he used his original name "Muhammad Sharif" but later on he adopted the name of Naseem Hijazi on the advice of his teacher which he retained till death.
Establishment of Pakistan is supposed to be a miracle of the known history due to the fact that under the prevailing unfavorable conditions it was almost unimaginable for the Muslims of the Subcontinent to achieve their separate homeland in the face of strong opposition by the British government as well as the Hindu population. However, the passionate leadership of Quaid-e-Azam brought them together to a united platform and rekindled the spirit of freedom that enabled them to materialize the dream of an independent Pakistan within a short span of time. It is a timeless and undeniable fact that the Muslims of the Subcontinent offered immense sacrifices for Pakistan and each and every person from all spheres of life dedicated all their energies and made every possible effort for this cause.

Services rendered by the leaders of this unparalleled struggle for the establishment of Pakistan are a part of history which has been mentioned in detail by almost every writer whether national or international in their writing works about the Pakistan Movement. These leaders are treated as the vanguards of this historic movement. However, the rear many who sacrificed whatever they had for their separate homeland only to receive nothing in return and instead, remain obscured for rest of their life. On the other hand fruits of the freedom were enjoyed by those who did nothing but a symbolic contribution to the fight for freedom. One can find many even today boasting to be honored to greet with the Quaid or to have attended some gathering along with him. Then there are others who describe the Quaid's visit to their locality and their presence there as if the establishment of Pakistan was almost impossible without this very contribution. Such people have not only received more than their due share but have also been awarded with sorts of honors for their well-trumpeted role and contribution to the Pakistan Movement.

Every year the 14th August day, the 23rd March day and other historic occasions are celebrated by honoring those with medals and awards who made some sort of contribution to the Pakistan Movement but no one knows 
where these people come from. They are showered with praises and accolade at the expense of those who made their mark to this remarkable struggle selflessly and without caring for any acknowledgment. Naseem Hejazi is one of such personalities who dedicated themselves with their body and soul for the freedom movement. However, all his sacrifices and services remained unacknowledged during his life as well as after his death. Strangely enough one can find his name mentioned by Baloch intellectuals in their works on the history and journalism of Baluchistan as the sole flag bearer of the accession of Baluchistan to Pakistan who responded with all his strength to the conspiracies of the Raj and the heinous propaganda run by the Congress through his newspaper named "Tanzeem".

It is also mentioned that if Naseem Hejazi was not there in Baluchistan, the largest province in terms of area, would have never become a part of the newly established state of Pakistan. Baloch leaders have not only appreciated his contributions but they also acknowledge that it was only because of Naseem Hejazi that The Congress failed in its nefarious designs. Pakistanism ran in his blood and he had a strong detestation for subjugation to Hindus since his youth. During an interview with Radio Pakistan Islamabad on May 20, 1986 Naseem Hejazi said:

"During my student life I could not even imagine to be ruled by Hindus. I had inherited my detestation for Congress and the Brahman politics from my forefathers. I had a strong desire in my heart that a day had to come when Muslims of the Subcontinent were going to build their own ideological fortress."

\section{Literature Review}

Nawabzada Jahangir Khan who made untiring efforts for Pakistan Movement as well as the accession of Baluchistan to Pakistan, while acknowledging his contribution to the Pakistan Movement and his efforts for accession to Pakistan said:

"I swear if Naseem Hejazi was not there in Baluchistan those days, accession of Baluchistan to Pakistan would have remained doubtful. (Kousar, Inaamul Huq, 1991: 370)"

All over the subcontinent Muslims were struggling for materializing their dream of independence. On the other hand every possible effort was being made to turn this struggle into a failure. Since 1876 to 1935 fundamental rights of the people of Baluchistan remained suspended and even they were not allowed to raise their voice for their rights; leave political organizations they were not even allowed to read newspapers; mentioning the words like independence and sovereignty was almost impossible.

Despite these difficult conditions Baluchistan people stood up against the Raj several times. First it was under the leadership of Mir Mehrab Khan. Then Ghulam Hussain Masoori confronted the British with his 1300 men where he and his 200 men were martyred. Shahjahan Jogezai also fought a number of wars against the British. Nawab Yousuf Ali Khan Aziz Magsi was also a harbinger of political awareness in Baluchistan. He helped launch a number of newspapers from Karachi including "Al-Baloch", "Baluchistan", "Baluchistan Jadeed" and "Young Baluchistan" which were confiscated successively. Although Baluchistan was an area with clear Muslim majority All India Muslim League came here into being very late. Baluchistan people were almost unaware of its activities. It was being propagated by National Congress that the Muslim League was a party of pro-government people but they could not misguide the courageous and honorable people of Baluchistan for very long.

\section{Comments of Nawabzada Jahangir Khan Jogezai}

\author{
Nawabzada Jahangir Khan Jogezai writes:
}

"Viewing the inevitability of the independence of Subcontinent and the loosening grip of imperial tyranny, the British given the geopolitical significance and mineral resources of the isolated province of Baluchistan launched a web of conspiracies to achieve their desired solution where they could maintain their influence over Baluchistan being separate from Hindustan and exploit its natural resources as well to support their economy and build a fortress against Russia to retain their supremacy. (Kausar, Inaamul Haq, 1991: 308)"

As the Pakistan Movement moved towards its destination the British and the Hindus reinforced their machinations and intrigues while some hysterical minds engaged in rioting. Destruction caused by the riots in March-April 1947 deteriorated to the extent where Quaid-e-Azam and Gandhi had to publish a collective call for peace. Naseem Hejazi's contribution to the freedom movement and the accession of Baluchistan to Pakistan had started way back from the day when he separated from Daily "Zamana" Karachi to leave for Baluchistan. His inclination towards the nationalist movements launched in the Subcontinent was an old affair. He said:

"Since my early days I had an inclination towards the Muslim League's mission and the Pakistan Movement. I wanted to envision my destination and for that I had to visit different areas and finally my quest brought me to Karachi. (Farooq, Syed 1977:66)"

At Daily "Zamana" Karachi, he continued working for the Pakistan Movement fearlessly. However, viewing the rising popularity of Pakistan Movement due to Daily "Zamana" the Congress ministry of Sindh secretly offered the newspaper owner with some monetary benefits. Once Naseem Hejazi came to know about receiving of the funds by his owner he wrote an editorial against "War Fund" and separated from the newspaper as he thought his newspaper was no more sincere with its mission and the cause. Later 
he had the opportunity to meet Mir Jaffer Khan Jamali through Sheikh Maqbool-ul-Haq. Initially, he was reluctant as he knew the feudal mindset. However, when he came to know that Mir Jaffer Khan Jamali was synonymous to the Pakistan Movement in Baluchistan he agreed on his patronization for his literary work. Meanwhile he spent

Most of his time in political activities, he proactively participated in organizing different activities of the Pakistan Movement in Baluchistan. Describing these days he said:

"Over a period of nine years I remained part of the political drama running across Baluchistan not as a spectator but as a character. (Farooq 1977: 117)"

\section{PhD Thesis on Hijazi}

A $\mathrm{PhD}$ thesis written on Hijazi's writing, titled "The Critical and Explorative Analysis of Nasima Hijazi's Historical Novel Writing" Transliteration "NASIMHIJAZI KI TAREEKHY NOVEL NIGARY KA TEHQIQI AUR TANQIDI TAJZIA" By Mumtaz Umar, University of the Karachi, Karachi.

Meanwhile Mir Jaffer Khan Jamali launched a newspaper "Tanzeem" from Quetta and assigned Naseem Hijazi with its editorship. He remained at the forefront for defending the ideological boundaries of the nation through this newspaper. He was passionate about winning a separate homeland, Pakistan, which led him to his struggle for accession of Baluchistan to Pakistan. One can never separate his name from this movement. Nawabzada Jahangir Khan Jogezai writes:

"I met Naseem Hejazi for the first time at Mir Jaffer Khan Jamali's place; however, his name was not new to me. I already knew him very well as a companion of Mir Jaffer Khan Jamali and the editor of the 'Tanzeem'. I knew that the voice of Naseem Hejazi being heard in the political arena of Baluchistan was increasingly becoming the voice of the enlightened people of Baluchistan. (Farooq 1977: 118)"

Jahangir Khan Jogezai wrote further that my impression about him was that of a person who knew Baluchistan just like the lines on his hand. He countered the misleading propaganda of Congress through his newspaper "Tanzeem." Naseem Hejazi was blessed with a passion that could electrify any of his companions. Describing his relationship with Naseem Hejazi, Syed Has him Raza during a radio interview said that during 1940-47, Muslim League was the only party striving for the achievement of Pakistan. All those people who stood by Quaid-e-Azam during those times were respectable and Naseem Hejazi was also one of them. I think half of the propaganda campaign in favor of Muslim League in Baluchistan was run by Naseem Hejazi and the other half by Mir Jaffer Khan Jamali. "Pasban" Fortnightly, Quetta; June 15 (1939: 6).

The foremost purpose of Naseem Hejazi going to Baluchistan was to be part of Pakistan Movement. In an interview he said:

"In 1942 my passion for Pakistan took me to the place where I was needed. I went to Baluchistan as a companion of Mir Jaffer Khan Jamali where I spent most of my time reading books and analyzing the situation in Baluchistan. Dream for Pakistan was closer to my heart than any wealth in the world. (A Radio conversation; courtesy: Radio Pakistan, Rawalpindi, July 12,1985.)

\section{First Conference in Baluchistan by Muslim League}

When Muslim League launched its activities in Baluchistan some of the most popular local leaders were those who used to promote a united Hindustan. Muslim League held its first conference in Baluchistan on June 10-11 in Quetta. Maulana Zafar Ali Khan came to Quetta in July-August 1939 and visited all over Baluchistan. In June 1943, Quaid-e-Azam came to Baluchistan to invite Baluchistan people to join Muslim League. He also advised the Muslims not to be fragmented and get united under the flag of a single political party. Viewing the rising power of the Pakistan Movement the British had come to realize that partition of Hindustan was inevitable. However, it was their utmost desire to not let Baluchistan become a part of newly established state of Pakistan.

\section{Love for Pakistan}

His love for Pakistan and the Pakistan Movement had become his real asset. He would spend his days and nights making his contribution to this struggle. He said: "Without Pakistan I could not imagine a single day in my life and every other personal desire was inferior to this passion. 1945-47 were the busiest years in my life. Most of my time was spent in the service of the Pakistan Movement and secondly there was nothing else in my life but the efforts for accession of Baluchistan to Pakistan. It was at its peak from 1st August to 14th August when I could spare hardly two-and-a-half/ three hours on average for my work. (Iqra 1976:147-148) "

During the peak days of the Pakistan Movement the adversaries had opened three fronts against this struggle. British wanted Khan of Qallat to announce his independence and autonomy to support the Great Britain as its protectorate. The other hand Abdul Samad Khan Achakzai, Mirza Faizullah Abdul Qadir and Chandarman Wakeel were making efforts for accession of Baluchistan to India while the third front was opened by those struggling for their rights. Naseem Hejazi was fighting at all these fronts very efficiently and effectively

\section{Statement of Nawabzada Jahangir Khan about Hijazi}


As said by Nawabzada Jahangir Khan, "Following the Naseem Hejazi's arrival in Quetta the Pakistan Movement had become not a single party movement but a national movement."Naseem Hejazi was endeavoring for creating awareness about the Pakistan Movement in Baluchistan people. He was optimistic about his cause despite all conspiracies wrought by the British and the Hindus. He was well aware of discrimination faced by Muslims at the hands of Hindus. Sustaining the humiliation of Muslims was the most hurtful thing for him. Muslim League had launched its operations in Baluchistan while Naseem Hejazi and his comrades added more strength to this movement. Nawabzada Muhammad Khan Jogezai election to the Constitutional Assembly as advised by Naseem Hejazi was a step forward towards the accession of Baluchistan to Pakistan. It was Naseem Hejazi who advised Nawabzada Muhammad Khan Jogezai to contest elections against Congress candidate and not to leave the field open. Following a prolonged debate Nawabzada Muhammad Khan Jogezai was convinced about participating elections.

\section{Shahi Jirga}

To support their conspiracies the British assigned Shahi Jirga with the decision for Baluchistan's fate as it had an acclaimed and well-powered status of a legislative assembly. Nawabzada supported Muslim League in the Constitutional Assembly and paved the way for accession of Baluchistan to Pakistan. Naseem Hejazi would hold meetings with the Jirga members during nighttime to convince them about joining Pakistan and during the daytime he would write articles in his newspaper "Tanzeem" not only to guide Muslims but also to counter enemy's intrigues. June 29, 1947 was the date fixed for referendum in Baluchistan and a verdict in Pakistan's favor seemed too difficult. However, Naseem Hejazi worked day and night to defeat all these conspiracies successfully.

He wrote a special editorial titled "Lamha-e-Fikriya" in weekly "Tanzeem" dated June 16, 1947 to divert the attention of the central leadership of the Muslim League to the deteriorating conditions in Baluchistan. He wrote that one cannot even imagine a Pakistan without Baluchistan. He also arranged for a discussion between Quaid-e-Azam and the tribal chiefs of Baluchistan which led tribal chiefs to support Pakistan. He wrote in this regard: "Today as I write a chapter of the Baluchistan's history I can say this without any reluctance that during the referendum war in Baluchistan Masood Khaddarposh proved to be the best of the soldiers of Pakistan and a concrete wall in its fortress. It was a mere coincidence that a young ICS officer emerged as a beacon of light for our staggering boat and a young EAC served as a steward of the boat. (Raja Tasadduq Hussain 1987:190)"

\section{Biased Role of Congress}

Congress successfully converted some of the Shahi Jirga members to its tribe. These Tribal Lords were scared of losing their lordship in case Pakistan comes into being. It was being propagated as the end of tribal system and violation of the rights of Baloch people. Data about the income and expenses of Baluchistan was published as an attempt to prove that accession to Pakistan was a lost bargain. Congress also raised the slogan of sovereign Pathanistan to win the hearts of pathan population. Baloch and Pathan were being scared of some sort of mutual enslavement. A feeler about an announcement of independent Baluchistan or its accession to Afghanistan was also aired. Nawab Muhammad Khan Jogezai was offered with Rs180 Million by the Congress at a time when Baluchistan's income totaled not more than 15 Million only.

\section{Hijazi's Publications}

Khaak aur Khoon ("Dirt and Blood")Yousuf bin Tashfin ("Yousuf the Son of Tashfin") Akhari Chattan (Volume-1) Online ("The Last Rock") Akhari Chattan (Volume-2) Online ("The Last Rock") Aakhari Marka ("The Last Battle")Andheri Raat Ke Musafir ("Travelers of the Dark Night")Aur Talwar Toot Gai (Volume-1) ("And the Sword was Broken") Aur Talwar Toot Gai (Volume-2) ("And the Sword was Broken") Daastaan-e-Mujahid ("Tale of the Fighter)Gumshuda Qaafley' ("The Lost Caravans") Insaan Aur Devta ("The Human and the Deity") Kaleesa Aur Aag ("Church and Fire") Muhammad Bin Qasim Pakistan Se Diyare Haram Tak Pardesi Darakht ("The Alien Tree") Pouras Ke Hathi ("Poras's Elephants") Qafla-e-Hijaz' ("The Caravan of Hijaz") Qaisar-o-Kisra ("Caesar and Kisra")Saqafat Ki Talaash ("In Search of Culture") Shaheen (Volume-1) ("The Eagle") Shaheen (Volume-2) ("The Eagle")So Saal Baad' ("After 100 Years") Sufaid Jazeera ("The White Island")

However, all these intriguing moves by the Congress were out rightly defeated by Naseem Hejazi's powerful writings; all efforts to create misperceptions were foiled; sensing the conspiracies wrought by the Congress Naseem Hejazi took it upon him to respond to it in a deserving manner. He told Nawabzada Jahangir Khan that we had had enough of British dramatics and now it's our turn to present the final act of this play being run at the Baluchistan's stage. Naseem Hejazi managed to get some clue of the proceedings going to happen at Town Hall on June 29. He tried his best to get a decision on Baluchistan's fate on this very date. He also brought Nawab Jogezai around on refusing to accept Lord Mountbatten's demand for buying more time and announce in favor of Pakistan. Therefore, the moment Mr. Jeffery Prayer began with reading out Lord Mountbatten's order Nawab stood up confidently and said:

\footnotetext{
"We need no more time for the decision as the chiefs of the Tribal Jirga have given their verdict in favor of Pakistan. We hereby announce that our representative will be a part
} 
of the Constitutional Assembly of Pakistan and all those against this decision can part their ways right now.( Tanzeem, Weekly, Quetta, December 23, 1945; "Nizam", Karachi; March 20,1947)"

Thus all other chiefs put their weight in favor of Pakistan and Mr. Jeffery Pryer declared that he would send a telegram to the Viceroy informing him about the Jirga's decision in favor of Pakistan. Listening to this announcement Naseem Hejazi enthusiastically came outside and raised a slogan of "Pakistan Zindabad." So this is how Naseem Hejazi with his foresightedness made the accession of Baluchistan to Pakistan possible.

\section{Hijazi on Screen}

Three of Hijazi's novels have been dramatized. Akhri Chataan and Shaheen were dramatized in 1980s and were televised on Pakistan Television Corporation (PTV) as independent drama serials. Akhri Chataan is considered to be the greatest historical fiction attempt ever made by PTV. The theme songs composed for the serial and the character play of Sultan Jalal ud-Din by Salim Nasir earned high acclaim.

The Novel Khaak aur Khoon was dramatized into a movie with the same name and is one of few blockbuster movies that Lollywood or Lahore film industry has ever produced.

However, it is unfortunate that his significant contribution to the Pakistan Movement is almost forgotten and no one even mentions of his services. Nawab Muhammad Khan Jogezai who refused a Congress offer of Rs. 180 Million at a time when income of the whole Baluchistan totaled just Rs. 15 Million, unequivocally acknowledged that Naseem Hejazi had a vital role in accession of Baluchistan to Pakistan but one fails to find his mention in the books written on the Pakistan Movement. It means writers and historians either know nothing about him or they ignore him intentionally while his role in accession of Baluchistan to Pakistan is a living reality. Such a situation demands that the books on the Pakistan Movement should be reviewed to acknowledge Naseem Hejazi's contribution as the nations alive of their history never forget their benefactors.

\section{REFERENCES}

[1] A Radio conversation; courtesy: Radio Pakistan, Rawalpindi

[2] Hejazi, Naseem, (1986); Radio Transmission, Radio Pakistan, Islamabad; May 20, 1986

[3] Kausar, Inaamul Haq, Dr.(1991);"Jaddojehed-e-Azadi main Baluchistan ka kirdar"; Idara Tehqeeqaat-e-Pakistan, Danish Gah, Punjab, Lahore, and Printed by: Azhar Sons Printers, 108, Litton Road, Lahore; p: 370

[4] Kausar, Inaamul Haq, Dr.(1991);“Jaddojehed-e-Azadi main Baluchistan ka kirdar”; Idara Tehqeeqaat-e-Pakistan, Danish Gah, Punjab, Lahore, and Printed by: Azhar Sons Printers, 108, Litton Road, Lahore; p: 308

[5] Farooq, M. Syed, A. (1977); “Tehreek-e-Pakistan aur Baluchistan"; Mehran Publications, Tariq Road, Karachi; p: 1

[6] Farooq, M. Syed, A. (1977); "Tehreek-e-Pakistan aur Baluchistan"; Mehran Publications, Tariq Road, Karachi; p: 18

[7] Farooq, M. Syed, A. (1977); "Tehreek-e-Pakistan aur Baluchistan"; Mehran Publications, Tariq Road, Karachi; p: 66

[8] “Pasban” Fortnightly, Quetta; June 15 (1939); p: 6

[9] Iqra (1976)," Quaid-e-Azam Number,". Government M.A.O College, Lahore; Volume II; June 1976; p: 147-148

[10] Raja Tasadduq Hussain Dr. (1987); "Naseem Hejazi, ekmutalea"; Qaumi Kutab Khana, 19 Ferozpur Road, Lahore; p: 190

[11] Tanzeem, Weekly, Quetta, December 23, 1945; "Nizam", Karachi; March 20,1947 